\title{
Antibacterial cellulose-based aerogels for wound healing application: A review
}

\author{
Esam Bashir Yahya ${ }^{1, *(\infty)}$, Marwa Mohammed Alzalouk ${ }^{2}$, Khalifa A. Alfallous ${ }^{3}$, Abdullah F. Abogmaza ${ }^{3}$
}

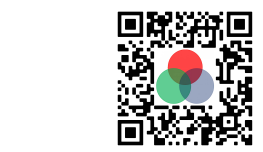

Use your smartphone to scan this QR code and download this article
${ }^{1}$ School of Industrial Technology, Universiti Sains Malaysia, Penang 11800, Malaysia

${ }^{2}$ Medical Technology College, Misurata University, 2478 Misurata, Libya

${ }^{3}$ Faculty of Science, Al-asmarya Islamic University, Zliten 00218, Libya

Correspondence

Esam Bashir Yahya, School of Industrial Technology, Universiti Sains Malaysia, Penang 11800, Malaysia

Email: essam912013@gmail.com

History

- Received: Aug 01, 2020

- Accepted: Sep 18, 2020

- Published: Oct 12, 2020

DOI : 10.15419/bmrat.v7i10.637

\section{Check for updates}

\section{Copyright}

(C) Biomedpress. This is an openaccess article distributed under the terms of the Creative Commons Attribution 4.0 International license.

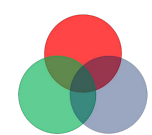

The Open Access Publisher

\begin{abstract}
Aerogels have been steadily developed since its first invention to become one of the most promising materials for various medical and non-medical applications. It has been prepared from organic and inorganic materials, in pure forms or composites. Cellulose-based aerogels are considered one of the promising materials in biomedical applications due to their availability, degradability, biocompatibility and non-cytotoxicity compared to conventional silica or metal-based aerogels. The unique properties of such materials permit their utilization in drug delivery, biosensing, tissue engineering scaffolds, and wound dressing. This review presents a summary of aerogel development as well as the properties and applications of aerogels. Herein, we further discuss the recent works pertaining to utilization of cellulose-based aerogels for antibacterial delivery.
\end{abstract}

Key words: aerogel, cellulose based, antibacterial, drug delivery, wound healing

\section{INTRODUCTION}

Aerogels have been defined as materials composed of more than $99 \%$ air; they can be prepared from various organic or inorganic precursors and are often manufactured in multi-shape structures to serve different needs ${ }^{1}$. S. Kistler made the initial aerogel in 1931, as a result of replacing the liquid of the gel with gas without changing the intact structure. He used silica gel as a precursor material in his first preparation ${ }^{2}$. A few years later, aerogels were steadily developed and were prepared from organic, inorganic, hybrid and even different composites of materials. Biopolymers and, particularly, cellulose have gained a lot of popularity among scientists in terms of aerogel preparation, especially in biomedical applications. They have been utilized in wound healing, tissue engineering scaffolds, and drug delivery ${ }^{3,4}$. Even non-medical applications have benefited from aerogels. Many scientists have joined the race to develop and fabricate such materials to serve humanity in many applications, including insulation ${ }^{5,6}$, absorption $^{7,8}$, packaging ${ }^{9,10}$, supercapacitors ${ }^{11,12}$, catalysts $^{13,14}$, energy storage ${ }^{15,16}$, filtration ${ }^{17,18}$, conduction $^{19,20}$, sensing ${ }^{21,22}$, cleaning, and adsorption of wastes ${ }^{23,24}$. Figure 1 shows the summary of different non-medical applications of aerogels. However, despite the huge number of developed aerogels, the commercialization process has been still relatively slow. Meanwhile, the number of companies producing aerogels is steadily increasing to provide high performance materials for different applications.
Cellulose is the most abundant polymer on earth. It have been obtained mainly from plant and bacterial sources ${ }^{25}$. However, it is one of the most used polymers in aerogel preparation due to its unique properties, such as biodegradability, biocompatibility and negligible cytotoxicity ${ }^{26}$. Cellulose-based aerogels have been widely used in many medical applications, such as biosensing, drug delivery, tissue scaffolding, and antibacterial materials for wound dressing.

There are already several excellent review articles discussing cellulose-based aerogels, such as one by $\mathrm{Ab}$ dul Khalil, H. P. S et al. ${ }^{1}$ which further discusses the chronological development of aerogels and the biomedical applications of cellulose nanofiber-based aerogels. Other reviews have discussed the chemistry and physics beyond their synthesis and their different applications ${ }^{27,28}$. However, not much has been investigated regarding the use of cellulose-based aerogels for antibacterial delivery or wound dressing. We anticipate that many more new aerogel types will be discovered in the next few years. Many other new combinations need to be discovered. Indeed, the interest in aerogels just keeps growing as indicated by the number of publications each year. This current review provides an overview on aerogels and their development, we well as discusses the recent works using cellulosebased aerogels for antibacterial delivery.

\section{DEVELOPMENT OF AEROGELS}

Since its invention back in the 1930s, research studies on aerogels have steadily risen. The father/founder 


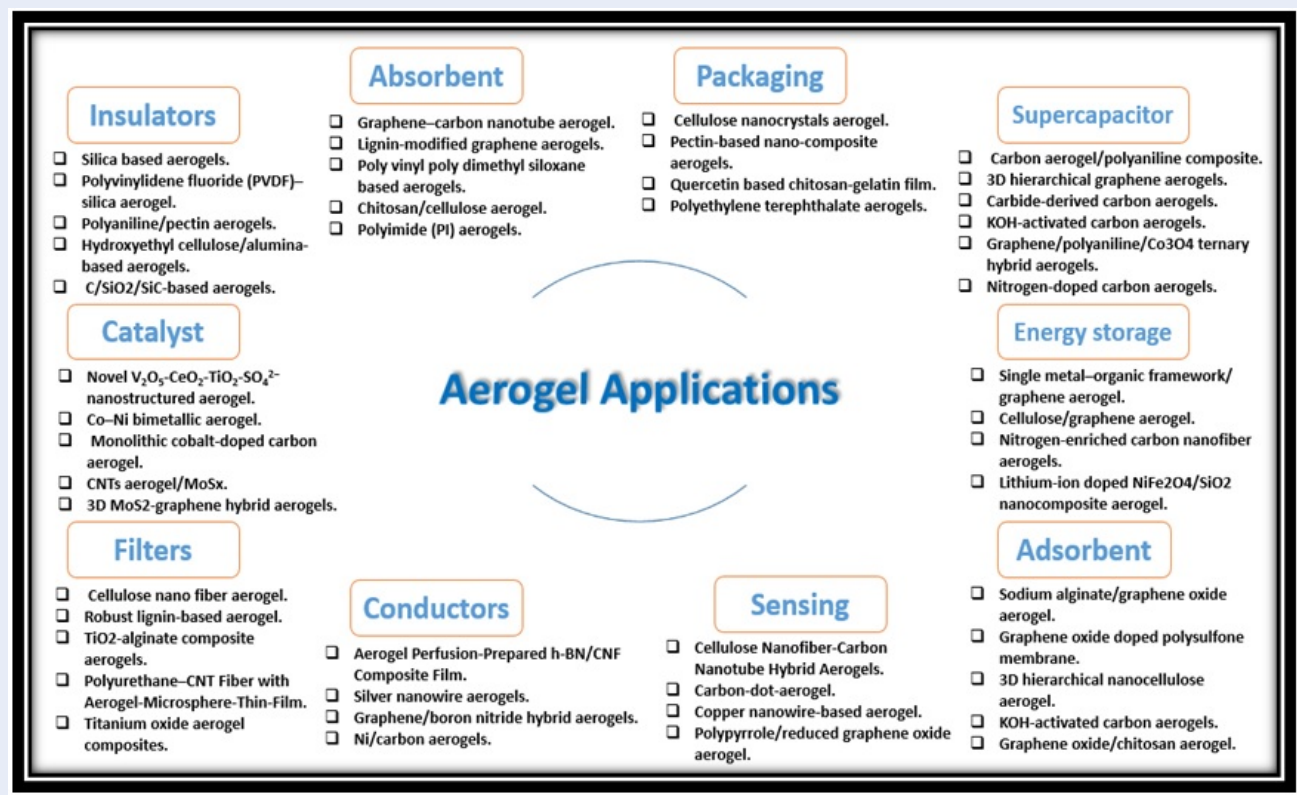

Figure 1: Summary of different non-medical applications of aerogels since its invention with examples of the most commonly used types of aerogel for each application.

of aerogel, S. Kistler, described his first invention as replacement of the liquid in the gel with gas, while keeping the gel's structure intact ${ }^{29}$. One year later, the same scientist prepared many aerogels from different materials, including metal oxides and some organic materials, following the same approach. Figure 2 summarizes some of the important events regarding the evolution of aerogels. As a liquid-free network, aerogels can be defined as solid, ultra-lightweight and lucid open porous networks obtained from the gel following the removal of the liquid without any significant modification in the network structure ${ }^{30}$. The physical, chemical and mechanical properties of this network depends on the material or group of materials that form this network.

The chemistry of aerogels is very flexible and has been reported to be altered by many factors, such as the precursor materials ${ }^{31}$, their ratios ${ }^{32}$, preparation approaches $^{33}$, and so on. The pore size and surface area of aerogels can also be tailored ${ }^{34}$. Furthermore, different functional groups have been implemented in the aerogels to provide desired mechanical and physico-chemical properties ${ }^{35}$. Particularly, hybrid aerogels are able to have their properties modified and new functionalities added, depending on the target application. On the other hand, if the properties of aerogels were improved, new applications which were impossible in the past would be enabled in the future ${ }^{36}$.

\section{CELLULOSE-BASED AEROGELS}

Cellulose is one of the most utilized biopolymers in aerogel preparations; studies on biopolymers have been motivated by the search for sustainable precursors instead of using traditional oil-based or synthetic polymers $^{3}$. Cellulose has many advantages over other conventional biopolymers, namely that it is among the most abundant biopolymers on earth and can be extracted from different sources ${ }^{37-39}$. Apart from plants, cellulose has been extracted using static culturing of many types of bacteria, such as Acetobacter xylinum ${ }^{40}$. Bacterial cellulose has the advantage of having a higher degree of crystallinity ${ }^{41}$ and occurring in pure form without any impurities, such as lignin and hemicellulose. Nanocellulose is a term referring to cellulose materials that have nanoscale dimensions ( 1 to $100 \mathrm{~nm}$ ), which include either cellulose nanocrystals (CNC) or cellulose nanofibers $(\mathrm{CNF})^{42}$. Both CNC and CNF display unique properties, including high surface area and high strength, as well as tunable surface chemistry, allowing for controlled interactions with other polymers, nanoparticles, biological materials and/or small molecules ${ }^{33}$.

\section{Properties of cellulose-based aerogels}

Cellulose-based aerogel is a highly porous nanostructured material which displays the typical features of aerogels with many advantages. Nano-cellulose 


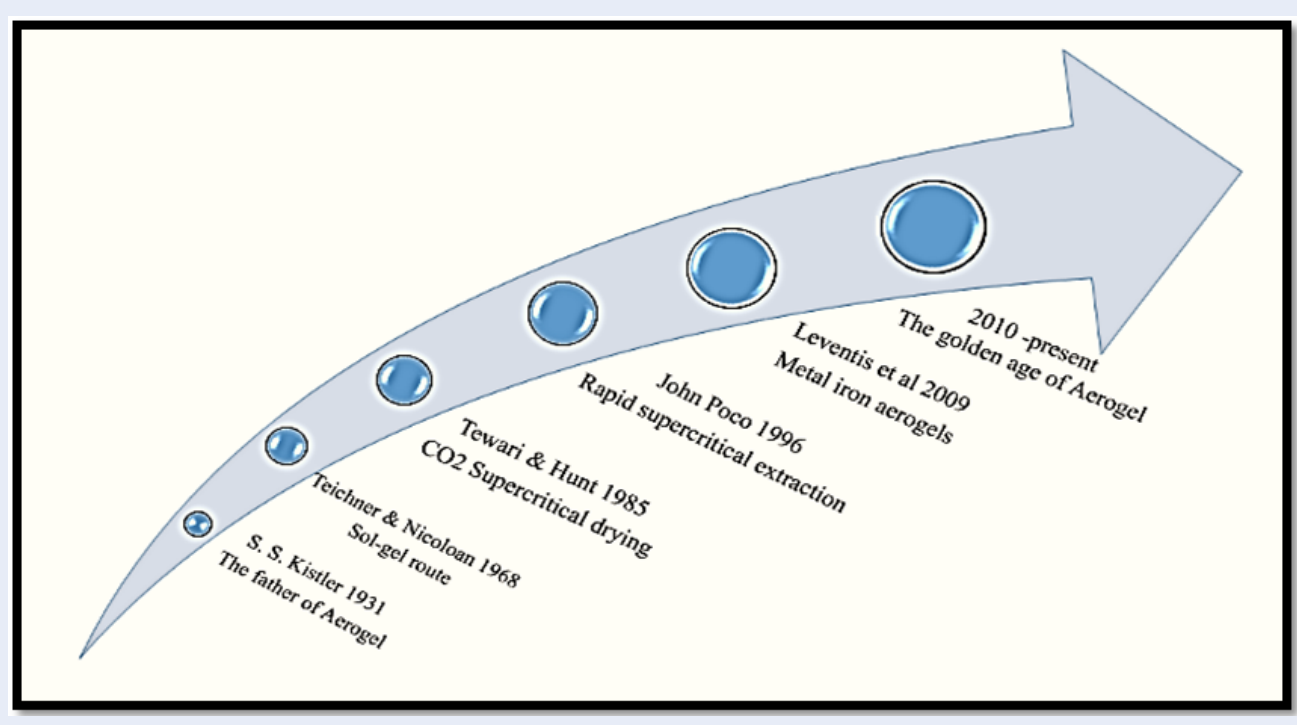

Figure 2: The main chronological events of aerogel development since its first invention until the present.

materials, including cellulose nanofiber and cellulose nanocrystals, are attracting increasing interest among scientists. Indeed, every year, a large number of research studies are conducted on them. The unique properties of this material, including high mechanical strength, high degree of polymerization, high purity and high crystallinity, make it a promising material for preparing aerogels with characteristics of flexibility and pressure resistance ${ }^{43,44}$. Zhang, T. et al. ${ }^{45}$ compared the morphological structure of each of the $\mathrm{CNF}$ and CNC aerogels individually, and in different mixed ratios as presented in Figure 3. They reported that mixed (CNC and CNF) aerogels show better performance than the pure aerogels of each of them. However, all the aerogels that they prepared had 3D network structure and rich pores which were formed by the disorder of the growing ice crystals. It can be observed in the obtained SEM figures that there are some differences in the morphology; CNCbased aerogel is spherical in shape while the CNFbased aerogel is rice-shaped, which results from the longer filament of CNF compared to CNC.

The mechanical properties of aerogels have been reported to be affected by two main factors: precursor material and preparation method ${ }^{46}$. Cellulose is used to enhance the mechanical properties of many hybrid aerogels. J Yang et al. ${ }^{47}$ reported that cellulose enhances the mechanical properties of the aerogel, and that the ratio of alginate cellulose has a significant effect on the mechanical properties. In addition, using cellulose as the precursor material in aerogel preparation has many beneficial properties, including the functional groups on the surface of the cellulose chain which is considered as a cross-linking agent for many other materials. The possibility of regenerating or reusing cellulose is another advantage of the material; additionally, the chemical modification of cellulose improves its mechanical strength and the structural characteristics of cellulose aerogels are relatively easy to generate ${ }^{48}$.

\section{Biomedical applications of cellulose-based aerogels}

Recently, with the revolution of nanotechnology, many methods have been developed to isolate nanofibers, nanocrystals and nanoparticles from different materials. Nanocellulose-based aerogels show great promise in a wide range of biomedical, pharmaceutical, cosmetic, separation, energy storage, construction, and food applications ${ }^{41}$. Edwards, J. V et al. ${ }^{49}$ used peptide nanocellulose aerogels for biosensing; they fabricated aerogels with high porosity of $99 \%$ to detect protease enzyme activity. Their findings in term of mass spectral analysis and the physical properties of prepared aerogels were reported to be suitable for interfacing with an intelligent protease sequestrant wound dressing application.

Cellulose-based aerogels have been also utilized in many regeneration studies to regenerate many tissues and organs, such as bone, skin and cartilage. Cellulose-based aerogels have been suggested to solve the issue of the potential complications associated with autografts since they have been widely used in tissue engineering scaffold preparations. DA Osorio 


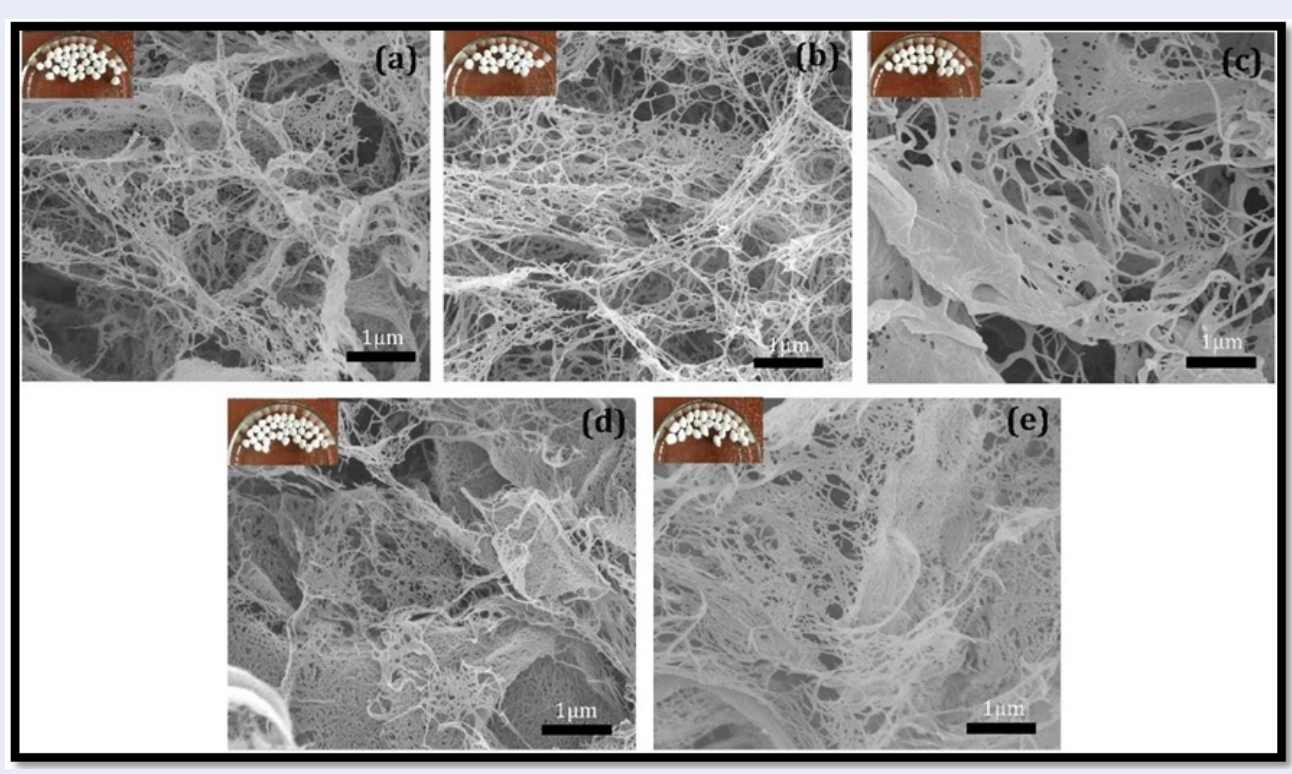

Figure 3: SEM images of aerogels prepared using different ratios of cellulose nanocrystals (CNC) and cellulose nano fibers (CNF): (a) CNC/CNF (3:1), (b) CNC/CNF (1:3), (c) CNC/CNF (1:1), (d) CNC, (e) CNF. Adapted from Zhang, et al. (2018) with permission from Elsevier ${ }^{45}$.

et al. ${ }^{50}$ have used for the first time modified cellulose nanocrystal aerogels as viable bone tissue scaffolds. Their findings demonstrate that cellulose-based aerogels are flexible and porous, and can effectively facilitate bone growth after they are implanted in bone defects. Other medical applications have benefited from cellulose aerogels. For instance, J Zhao et al. ${ }^{51}$ used a combination of polyethylenimine (PEI)-grafted cellulose nanofibril aerogels for drug delivery, and reported that the materials are promising and can be used as new generation controlled drug delivery carriers. The unique $\mathrm{pH}$ and temperature-responsiveness of cellulose-based aerogels, together with their excellent physical, chemical and mechanical properties, as well as their biodegradability, biocompatibility and low cytotoxicity, offer a simple and safe alternative to the conventional systems (synthetic polymers). Table 1 shows a summary of biomedical applications of cellulose-based aerogels.

\section{ANTIBACTERIAL APPLICATIONS OF CELLULOSE-BASED AEROGELS}

Many antibacterial-based materials have been immobilized inside the nanocellulose network upon the formation of aerogels; these materials retain their antibacterial activity resulting from the antibacterial aerogel. Various plant extracts and essential oils have been reported to possess extraordinary antibacterial activities. Yahya et al. ${ }^{64}$ reported that Punica granatum peel extract had stronger antibacterial activity than many common antibiotics. The authors tested their extract on three different species of bacteria and demonstrated it had strong antibacterial activity. Use of natural extracts together with cellulose-based aerogel is preferable in medical applications to avoid synthetic and chemical ingredients.

In another study, Khan et al. ${ }^{65}$ used silver nanoparticles and enzymes as antibacterial materials and immobilized these materials inside CNF aerogels. The authors evaluated their aerogel composites for their potential use in clinical trials. The results indicated the aerogels were non-toxic and biodegradable. Thus, the authors reported that cellulose nanofibers are a suitable support for bioactive materials and are effective in protecting and retaining enzymatic and antibacterial activities. Lu et al. ${ }^{66}$ prepared high porous (90 - 95\%) dialdehyde CNF/collagen composite aerogels which exhibited strong water absorption (up to $4000 \%$ ) and good biocompatibility. This aerogel composite can be enhanced with addition of plantbased antibacterial material that can prevent bacterial growth. The high capacity of aerogels to absorb water lends support to their potential use in wound dressing. Shan et al. ${ }^{67}$ have loaded Amoxicillin antibiotic inside of cellulose aerogel, aiming for better performance after they controlled amoxicillin release. The 
Table 1: Selected studies of different biomedical applications of cellulose based aerogels

\begin{tabular}{|c|c|c|c|}
\hline Application & Material & Summary & Ref \\
\hline \multirow[t]{3}{*}{$\begin{array}{l}\text { Drug } \\
\text { delivery }\end{array}$} & CNF aerogels & $\begin{array}{l}\text { Tested for oral controlled drug delivery \& resulting of improved in } \\
\text { bioavailability of drug. }\end{array}$ & 52 \\
\hline & $\begin{array}{l}\text { Cellulose triacetate } \\
\text { aerogel }\end{array}$ & $\begin{array}{l}\text { Test the influences of the size and the distribution of drug, aerogel } \\
\text { show high drug uptake and slow release rate }\end{array}$ & 53 \\
\hline & Cellulose aerogels & $\begin{array}{l}\text { Evaluated loading capacity and release kinetics, promising con- } \\
\text { trolled drug release carriers by exhibiting a high-loading capacity }\end{array}$ & 54 \\
\hline \multirow[t]{3}{*}{ Biosensing } & $\begin{array}{l}\text { Peptide/cellulosic } \\
\text { aerogel }\end{array}$ & $\begin{array}{l}\text { Successfully used a micro-titer enzyme assay to determine the re- } \\
\text { sponse, sensitivity, and kinetic behavior of the biosensor. }\end{array}$ & 55 \\
\hline & $\begin{array}{l}\text { Prussian } \\
\text { blue/cellulose } \\
\text { aerogel }\end{array}$ & $\begin{array}{l}\text { Tested as an orally administered drug, which was able to detect and } \\
\text { remove ingested cesium ions from the gastrointestinal tract. }\end{array}$ & 56 \\
\hline & CNC aerogel & $\begin{array}{l}\text { Evaluated a sensor to detect human neutrophil elastase for healing } \\
\text { chronic wounds. }\end{array}$ & 57 \\
\hline \multirow[t]{3}{*}{$\begin{array}{l}\text { Skin tissue } \\
\text { repair }\end{array}$} & Bacterial cellulose & $\begin{array}{l}\text { The using of aerogel had faster and better healing effect and less in- } \\
\text { flammatory response. }\end{array}$ & 58 \\
\hline & $\begin{array}{l}\text { Nanocellulose } \\
\text { aerogel }\end{array}$ & $\begin{array}{l}\text { Novel invention a promising process to fabricate bilayer aerogel for } \\
\text { skin repair. }\end{array}$ & 59 \\
\hline & $\begin{array}{l}\text { Amoxicillin/ Cellu- } \\
\text { lose aerogel }\end{array}$ & $\begin{array}{l}\text { Grafted amoxicillin onto the cellulose, and observed enhancement } \\
\text { of the antimicrobial activity against fungus bacteria. }\end{array}$ & 60 \\
\hline \multirow[t]{3}{*}{$\begin{array}{l}\text { Tissue } \\
\text { scaffolds }\end{array}$} & $\begin{array}{l}\text { CNF/ PEGDA } \\
\text { aerogel }\end{array}$ & $\begin{array}{l}\text { Possess good mechanical and biocompatibility, tested cells tightly } \\
\text { adhere and spread on the aerogel with good differentiation and vi- } \\
\text { ability. }\end{array}$ & 61 \\
\hline & $\begin{array}{l}\text { Cellulose/gelatin } \\
\text { aerogel }\end{array}$ & $\begin{array}{l}\text { Surface-modified scaffold for skin regeneration, showed good adhe- } \\
\text { sion and proliferation of keratinocytes during } 7 \text { days of incubation. }\end{array}$ & 62 \\
\hline & Pure CNC aerogel & $\begin{array}{l}\text { Various scaffolds structures successfully printed using direct ink } \\
\text { write technique. }\end{array}$ & 63 \\
\hline
\end{tabular}

antibiotic lost its effect against many types of bacteria due to the misuse of it; most of the bacteria had already developed resistance to this antibiotic. However, the authors reported that cellulose aerogels exhibited excellent antibacterial activity with the amoxicillin dose-dependent activity ${ }^{67}$. Immobilization of certain doses of antibiotic inside the aerogel network enhances the activity of the antibiotic, which has been demonstrated in a previous study ${ }^{68}$.

Cellulose has a unique surface chemistry, permitting it to cross-link with many materials, including protein extracts, antibiotics, and even metal nanoparticles $^{68}$. Zuguang et al. ${ }^{69}$ prepared hybrid cellulosebased aerogels using silver nanoparticles as antibacterial materials. The hybrid aerogel interestingly had a strong antibacterial effect against many bacterial species. The authors destroyed the crystalline region of cellulose and, partly, the oxidation of some groups to allow strong cross-linking of silver nanoparticles. This type of cellulose surface modification was done to enhance the ability of cellulose and prevent the potential release of nanoparticles that may cause some health risks in the long term. Many other studies have used silver nanoparticles, such as Salomoni et al. $(2017)^{70}$, Tang et al. $(2018)^{71}$ and Vijaya et al. $(2017)^{72}$, as antibacterial materials but due to the high cost of such materials and their potential health risk, they did not reach production or clinical trial stage. However, use of aerogels to immobilize the nanoparticles will significantly minimize the required dose to avoid their release and to facilitate the potential regeneration of the nanoparticles to be used over again. Henschen et al. ${ }^{73}$ prepared novel wet-stabilized aerogels that were able to retain their porosity after being soaked in water. In addition, their cellulose surfacemodified based aerogels were able to adhere to more than $99 \%$ of bacteria from the aqueous suspension. Microscopy analysis confirmed that surface modifications have been done to cellulose to allow for bacterial adherence $^{73}$. 
The findings of this study show the potential of creating 3D materials that have high efficiency to adsorb the bacteria and high porosity. Thus, the great surface area of aerogels in combination with their open structures gives the material high potential for bacterial removal. Use of cellulose-based aerogels as antibacterial materials has many environmentally advantages, such as being green, sustainable, biodegradable, abundant and non-environmentally taxing ${ }^{74}$. Numerous studies have evaluated biocompatibility and cytotoxicity of cellulose-based aerogels ${ }^{56,75-77}$, and concluded that there is no cytotoxicity that has been observed with cellulose-based aerogels. Cellulose aerogels facilitate cell adhesion and viability, and enhance cell growth and proliferation. In terms of wound dressing, as mentioned earlier from toxicity studies, cellulose aerogels can be safely incorporated with antibacterial substances and used as promising materials for wound dressing and healing.

The unique physical, chemical and mechanical properties, as well as biocompatibility, of cellulose-based aerogels make them excellent candidates for many purposes in the medical field. Hence, their biocompatibility enables them to be incorporated with other natural materials ${ }^{78}$ to obtain a green composite with specific properties. Essential oils have the potential to cross-link with cellulose particles ${ }^{79}$. R Moghimi et al. ${ }^{80}$ prepared antibacterial cellulose-based edible films for food packaging, using thymus essential oil as an antibacterial ingredient inside the film. Following this strategy, it was shown to be environmentally safe for producing green and sustainable materials for many applications. Another potential utilization of aerogels, as they are composed of up to $99 \%$ air $^{81}$ and per the previous explained strategy, is that it is possible to use antibacterial aerogels to cure chronic diabetic wounds and prevent the amputation of many limbs that are mainly caused by growth of anaerobic bacteria $^{82}$. Antibacterial aerogels will provide clean wounds and inhibit aerobic bacterial growth, without closing or preventing the aeration which is necessary for wound healing ${ }^{83}$.

However, in order to propose the safe use of cellulosebased aerogels for biomedical applications, it is important to evaluate the toxicity and fate of these materials. Recently, some authors raised important concerns that justify the study of bio-interactions and the possible impact to humans upon the exposure to nanocellulose materials. This would provide consistent and useful knowledge that can guide the regulations ${ }^{84-86}$. Most of the biological impact of materials have been studied by cytotoxicity evaluation assays. Acute and/or chronic toxicity of cellulose, nanocellulose-based materials during long-term exposure, occupational exposure at normal conditions, and exacerbation of pre-existing disease conditions must be studied. Furthermore, the concerns about using nanoparticles in medical applications must be further investigated in long-term studies. Cellulose nanomaterials and aerogels have both been prepared with different techniques, using a wide range of pretreatment and treatment chemicals, resulting in the same or modified final materials. Cytotoxicity studies have not yet been conducted for all the materials that have been fabricated. Another concern about the biological effects is that most of previous studies have evaluated the cytotoxicity of the materials using only one cell type and for a short period of time, which raises concerns about the possible effects on other cell types, in the short term and long term.

\section{CONCLUSION}

Cellulose-based aerogels have sustainability, renewability, biocompatibility, and biodegradability of cellulose but also have excellent properties such as low density, high porosity, and a high specific surface area, enabling them to be utilized in many applications including antibacterial applications. The materials have been successfully demonstrated for their ability to be used as antibacterial agents and for skin and tissue repair. This review discussed some applications of using cellulose-based aerogels as an antibacterial carrier, and highlighted the concerns about the possible biological effects of these materials. There is a need for more animal-based long-term studies on cellulose aerogels to eliminate concerns and ensure safety of their use in humans.

\section{ABBREVIATIONS}

CNC: cellulose nanocrystal

CNF: cellulose nano fiber

PEGDA: polyethylene glycol diacrylate

\section{ACKNOWLEDGMENTS}

None.

\section{AUTHOR'S CONTRIBUTIONS}

Conceptualisation, Esam Bashir Yahya; Software, Esam Bashir Yahya and Marwa Mohammed Alzalouk.; Resources, Khalifa A.Alfallous, and Abdullah F Abogmaza; Writing-review and editing, Esam Bashir Yahya. All authors have read and agreed to the published version of the manuscript.

\section{FUNDING}

This work did not receive any financially support. 


\section{AVAILABILITY OF DATA AND MATERIALS}

Not applicable.

\section{ETHICS APPROVAL AND CONSENT TO PARTICIPATE}

Not applicable.

\section{CONSENT FOR PUBLICATION}

Not applicable.

\section{COMPETING INTERESTS}

The authors declare that they have no competing interests.

\section{REFERENCES}

1. Abdul KH, et al. A Review on Plant Cellulose NanofibreBased Aerogels for Biomedical Applications. Polymers. 2020;12(8):1759. PMID: 32781602. Available from: https: //doi.org/10.3390/polym12081759.

2. Ziegler $C$, et al. Modern inorganic aerogels. Angewandte Chemie International Edition. 2017;56(43):1320013221. PMID: 28160389. Available from: https://doi.org/10. 1002/anie.201611552.

3. Zhao S, et al. Biopolymer aerogels and foams: Chemistry, properties, and applications. Angewandte Chemie International Edition. 2018;57(26):7580-7608. PMID: 29316086. Available from: https://doi.org/10.1002/anie.201709014.

4. Surya I, et al. Plasticizer Enhancement on the Miscibility and Thermomechanical Properties of Polylactic Acid-Chitin-Starch Composites. Polymers. 2020;12(1):115. PMID: 31948030. Available from: https://doi.org/10.3390/polym12010115.

5. Yang $\mathrm{S}$, et al. Inhibition of algae growth on HVDC polymeric insulators using antibiotic-loaded silica aerogel nanocomposites. Polymer Degradation and Stability. 2018;155:262-270. Available from: https://doi.org/10.1016/j.polymdegradstab.2018.07.024.

6. Ren $S$, et al. Preparation and characterization of organicinorganic hybrid ZrOC/PF aerogel used as high-temperature insulator. Ceramics International. 2020;46(5):6326-6332. Available from: https://doi.org/10.1016/j.ceramint.2019.11.107.

7. Wang Z, et al. Ultralight, highly compressible and fireretardant graphene aerogel with self-adjustable electromagnetic wave absorption. Carbon. 2018;139:1126-1135. Available from: https://doi.org/10.1016/j.carbon.2018.08.014.

8. Talebi Z, et al. Silica aerogel/polyester blankets for efficient sound absorption in buildings. Construction and Building Materials. 2019;220:76-89. Available from: https://doi.org/10. 1016/j.conbuildmat.2019.06.031.

9. Oliveira JP, et al. Cellulose nanocrystals from rice and oat husks and their application in aerogels for food packaging. International journal of biological macromolecules. 2019;124:175-184. PMID: 30471399. Available from: https: //doi.org/10.1016/j.ijbiomac.2018.11.205.

10. Fontes-Candia $C$, et al. Superabsorbent food packaging bioactive cellulose-based aerogels from Arundo donax waste biomass. Food Hydrocolloids. 2019;96:151-160. Available from: https://doi.org/10.1016/j.foodhyd.2019.05.011.

11. Wang $C$, et al. Synthesis and characterization of $3 D \mathrm{CoMoO}$ $4 / \mathrm{rGO}$ aerogel for supercapacitor electrodes. in 2018 19th International Conference on Electronic Packaging Technology (ICEPT). IEEE. 2018;Available from: https://doi.org/10.1109/ ICEPT.2018.8480680.

12. Zu G, et al. Nanocellulose-derived highly porous carbon aerogels for supercapacitors. Carbon. 2016;99:203-211. Available from: https://doi.org/10.1016/j.carbon.2015.11.079.
13. Arfaoui J, et al. Novel V2O5-CeO2-TiO2-SO42- nanostructured aerogel catalyst for the low temperature selective catalytic reduction of $\mathrm{NO}$ by NH3 in excess $\mathrm{O} 2$. Applied Catalysis B: Environmental. 2018;224:264-275. Available from: https: //doi.org/10.1016/j.apcatb.2017.10.059.

14. Deerattrakul V, et al. Characterization of supported Cu$\mathrm{Zn}$ /graphene aerogel catalyst for direct $\mathrm{CO} 2$ hydrogenation to methanol: Effect of hydrothermal temperature on graphene aerogel synthesis. Catalysis Today. 2018;314:154-163. Available from: https://doi.org/10.1016/j.cattod.2017.12.010.

15. Xia W, et al. High-performance energy storage and conversion materials derived from a single metal-organic framework/graphene aerogel composite. Nano letters. 2017;17(5):2788-2795. PMID: 28394621. Available from: https://doi.org/10.1021/acs.nanolett.6b05004.

16. Yang J, et al. Cellulose/graphene aerogel supported phase change composites with high thermal conductivity and good shape stability for thermal energy storage. Carbon. 2016;98:50-57. Available from: https://doi.org/10.1016/j. carbon.2015.10.082.

17. Dai J, et al. TiO2-alginate composite aerogels as nove oil/water separation and wastewater remediation filters. Composites Part B: Engineering. 2019;160:480-487. Available from: https://doi.org/10.1016/j.compositesb.2018.12.097.

18. Gajda J. Examination of filters modified with aerogel synthesized based on solvent mixtures. Katedra Inżynierii Procesów Zintegrowanych. 2018;

19. Qian F, et al. Ultralight conductive silver nanowire aerogels. Nano letters. 2017;17(12):7171-7176. PMID: 28872874. Available from: https://doi.org/10.1021/acs.nanolett.7b02790.

20. An F, et al. Highly anisotropic graphene/boron nitride hybrid aerogels with long-range ordered architecture and moderate density for highly thermally conductive composites. Carbon. 2018;126:119-127. Available from: https://doi.org/10.1016/j. carbon.2017.10.011.

21. Dolai S, Bhunia SK, Jelinek R. Carbon-dot-aerogel sensor for aromatic volatile organic compounds. Sensors and Actuators B: Chemical. 2017;241:607-613. Available from: https://doi org/10.1016/j.snb.2016.10.124.

22. Xu X, et al. Copper nanowire-based aerogel with tunable pore structure and its application as flexible pressure sensor. ACS applied materials \& interfaces. 2017;9(16):1427314280. PMID: 28398033. Available from: https://doi.org/10. 1021/acsami.7b02087.

23. Jiang F, Dinh DM, Hsieh YL. Adsorption and desorption of cationic malachite green dye on cellulose nanofibril aerogels. Carbohydrate polymers. 2017;173:286-294. PMID: 28732868 Available from: https://doi.org/10.1016/j.carbpol.2017.05.097.

24. Zhang $\mathrm{H}$, et al. Super light $3 \mathrm{D}$ hierarchical nanocellulose aerogel foam with superior oil adsorption. Journal of colloid and interface science. 2019;536:245-251. PMID: 30368096. Available from: https://doi.org/10.1016/j.jcis.2018.10.038.

25. Gong J, et al. Research on cellulose nanocrystals produced from cellulose sources with various polymorphs. RSC advances. 2017;7(53):33486-33493. Available from: https://doi. org/10.1039/C7RA06222B.

26. Dong $\mathrm{H}$, et al. The dual effects of carboxymethyl cellulose on the colloidal stability and toxicity of nanoscale zero-valent iron. Chemosphere. 2016;144:1682-1689. PMID: 26519799. Available from: https://doi.org/10.1016/j.chemosphere.2015. 10.066 .

27. Budtova T. Cellulose II aerogels: A review. Cellulose. 2019;26(1):81-121. Available from: https://doi.org/10.1007/ s10570-018-2189-1.

28. Wan C, et al. Functional nanocomposites from sustainable regenerated cellulose aerogels: A review. Chemical Engineering Journal. 2019;359:459-475. Available from: https://doi.org/10. 1016/j.cej.2018.11.115.

29. Kistler SS. Coherent expanded aerogels and jellies. Nature. 1931;127(3211):741-741. Available from: https://doi.org/10. 1038/127741a0. 
30. García-González CA, et al. An opinion paper on aerogels for biomedical and environmental applications. Molecules. 2019;24(9):1815. PMID: 31083427. Available from: https: //doi.org/10.3390/molecules24091815.

31. Alnaief $M$, Obaidat $R$, Mashaqbeh $H$. Effect of processing parameters on preparation of carrageenan aerogel microparticles. Carbohydrate polymers. 2018;180:264-275. PMID: 29103505. Available from: https://doi.org/10.1016/j.carbpol. 2017.10.038.

32. Arenillas A, et al. Properties of Carbon Aerogels and Their Organic Precursors, in Organic and Carbon Gels. Springer. 2019;p. 87-121. Available from: https://doi.org/10.1007/9783-030-13897-4_3.

33. France KJ, Hoare T, Cranston ED. Review of hydrogels and aerogels containing nanocellulose. Chemistry of Materials. 2017;29(11):4609-4631. Available from: https://doi.org/10. 1021/acs.chemmater.7b00531.

34. Hu L, et al. Step-freeze-drying method for carbon aerogels: a study of the effects on microstructure and mechanical property. RSC advances. 2019;9(18):9931-9936. Available from: https://doi.org/10.1039/C9RA01328H.

35. Mahadik D, et al. Synthesis of multi-functional porous superhydrophobic trioxybenzene cross-linked silica aerogels with improved textural properties. Ceramics International. 2020;Available from: https://doi.org/10.1016/j.ceramint.2020. 04.110.

36. Smirnova I, Gurikov P. Aerogel production: Current status, research directions, and future opportunities. The Journal of Supercritical Fluids. 2018;134:228-233. Available from: https: //doi.org/10.1016/j.supflu.2017.12.037.

37. Yazdanbakhsh M, et al. Alpha-Cellulose Extraction from Wheat Bran for Preparing Cellulose Nanofibers. American Journal of Oil and Chemical Technologies. 2017;5(1).

38. Manzato $L$, et al. Optimization of cellulose extraction from jute fiber by Box-Behnken design. Fibers and Polymers. 2018;19(2):289-296. Available from: https://doi.org/10.1007/ s12221-018-1123-8.

39. Meng $F$, et al. Kinetic analysis of cellulose extraction from banana pseudo-stem by liquefaction in polyhydric alcohols. Industrial Crops and Products. 2019;137:377-385. Available from: https://doi.org/10.1016/j.indcrop.2019.05.025.

40. Lotfiman S, et al. Influence of date syrup as a carbon source on bacterial cellulose production by Acetobacter xylinum 0416. Advances in Polymer Technology. 2018;37(4):10851091. Available from: https://doi.org/10.1002/adv.21759.

41. Long LY, Weng YX, Wang YZ. Cellulose aerogels: Synthesis, applications, and prospects. Polymers. 2018;10(6):623. PMID: 30966656. Available from: https://doi.org/10.3390/ polym 10060623.

42. Phanthong P. Nanocellulose: Extraction and application. Carbon Resources Conversion. 2018;1(1):32-43. Available from: https://doi.org/10.1016/j.crcon.2018.05.004.

43. Zhang Z, et al. Ultralightweight and flexible silylated nanocellulose sponges for the selective removal of oil from water. Chemistry of Materials. 2014;26(8):2659-2668. Available from: https://doi.org/10.1021/cm5004164.

44. Nuryawan A, et al. Enhancement of Oil Palm Waste Nanoparticles on the Properties and Characterization of Hybrid Plywood Biocomposites. Polymers. 2020;12(5):1007. PMID: 32349385. Available from: https://doi.org/10.3390/polym12051007.

45. Zhang T, et al. Characterization of the nano-cellulose aerogel from mixing CNF and CNC with different ratio. Materials Letters. 2018;229:103-106. Available from: https://doi.org/10. 1016/j.matlet.2018.06.101

46. Simón-Herrero $C$, et al. Effects of freeze-drying conditions on aerogel properties. Journal of Materials Science. 2016;51(19):8977-8985. Available from: https://doi.org/10. 1007/s10853-016-0148-5.

47. Yang J, et al. Super-elastic and highly hydrophobic/superoleophilic sodium alginate/cellulose aerogel for oil/water separation. Cellulose. 2018;25(6):3533-3544. Available from: https://doi.org/10.1007/s10570-018-1801-8.
48. Madyan OA, et al. Enhancing mechanical properties of clay aerogel composites: An overview. Composites Part B: Engineering. 2016;98:314-329. Available from: https://doi.org/10. 1016/j.compositesb.2016.04.059.

49. Edwards JV, et al. Preparation, characterization and activity of a peptide-cellulosic aerogel protease sensor from cotton. Sensors. 2016;16(11):1789. PMID: 27792201. Available from: https://doi.org/10.3390/s16111789.

50. Osorio DA, et al. Cross-linked cellulose nanocrystal aerogels as viable bone tissue scaffolds. Acta biomaterialia. 2019;87:152165. PMID: 30710708. Available from: https://doi.org/10.1016/ j.actbio.2019.01.049.

51. Zhao J, et al. Polyethylenimine-grafted cellulose nanofibril aerogels as versatile vehicles for drug delivery. ACS applied materials \& interfaces. 2015;7(4):2607-2615. PMID: 25562313. Available from: https://doi.org/10.1021/am507601m.

52. Bhandari J, et al. Cellulose nanofiber aerogel as a promising biomaterial for customized oral drug delivery. International journal of nanomedicine. 2017;12:2021. PMID: 28352172. Available from: https://doi.org/10.2147/IJN.S124318.

53. Wang C, Okubayashi S. 3D aerogel of cellulose triacetate with supercritical antisolvent process for drug delivery. The Journal of Supercritical Fluids. 2019;148:33-41. Available from: https: //doi.org/10.1016/j.supflu.2019.02.026.

54. Chin SF, Jimmy FB, Pang SC. Fabrication of Cellulose Aerogel from Sugarcane Bagasse as Drug Delivery Carriers. Journal of Physical Science. 2016;27(3).

55. Fontenot K. Peptide Derivatized Cellulosic Aerogel From Cotton As A Point Of Care Diagnostic Protease Sensor. In Abstracts Of Papers Of The American Chemical Society. Amer Chemical Soc 1155 16th St, Nw, Washington, Dc 20036 Usa. 2016;.

56. Lee I. Porous 3D Prussian blue/cellulose aerogel as a decorporation agent for removal of ingested cesium from the gastrointestinal tract. Scientific reports, 2018. 8(1): p. 1-14. ;PMID: 29540724. Available from: https://doi.org/10.1038/s41598018-22715-w.

57. Edwards JV, et al. Structure/function analysis of cotton-based peptide-cellulose conjugates: spatiotemporal/kinetic assessment of protease aerogels compared to nanocrystalline and paper cellulose. International journal of molecular sciences. 2018;19(3):840. PMID: 29534033. Available from: https://doi. org/10.3390/ijms19030840.

58. Fu L, et al. Skin tissue repair materials from bacterial cellulose by a multilayer fermentation method. Journal of Materials Chemistry. 2012;22(24):12349-12357. Available from: https://doi.org/10.1039/c2jm00134a.

59. Ghafari R. Fabrication and characterization of novel bilayer scaffold from nanocellulose based aerogel for skin tissue engineering applications. International journal of biological macromolecules. 2019;136:796-803. PMID: 31226370. Available from: https://doi.org/10.1016/j.ijbiomac.2019.06.104.

60. Ye S. Flexible amoxicillin-grafted bacterial cellulose sponges for wound dressing: in vitro and in vivo evaluation. ACS applied materials \& interfaces. 2018;10(6):5862-5870. PMID: 29345902. Available from: https://doi.org/10.1021/acsami. $7 \mathrm{~b} 16680$.

61. Tang A, et al. Nanocellulose/PEGDA aerogel scaffolds with tunable modulus prepared by stereolithography for threedimensional cell culture. Journal of Biomaterials Science, Polymer Edition. 2019;30(10):797-814. PMID: 30940007. Available from: https://doi.org/10.1080/09205063.2019.1602904.

62. Khan S. Preparation and structural characterization of surface modified microporous bacterial cellulose scaffolds: A potential material for skin regeneration applications in vitro and in vivo. International journal of biological macromolecules. 2018;117. PMID: 29894790. Available from: https://doi.org/10. 1016/j.ijbiomac.2018.06.044.

63. Li VCF, et al. Direct ink write (DIW) 3D printed cellulose nanocrystal aerogel structures. Scientific reports. 2017;7(1):18. PMID: 28808235. Available from: https://doi.org/10.1038/ 
s41598-017-07771-y

64. Yahya EB. Evaluation Of In-Vitroantibacterial Activity Of Aqueous And Alcoholic Extracts Of The Peels Punica Granatum And Olea Europaea Leaves. Journal Of Sciences And Technologies (Medical Science). 2018;2(1).

65. Uddin KM, et al. Retention of lysozyme activity by physical immobilization in nanocellulose aerogels and antibacterial effects. Cellulose. 2017;24(7):2837-2848. Available from: https://doi.org/10.1007/s10570-017-1311-0.

66. Lu T, et al. Composite aerogels based on dialdehyde nanocellulose and collagen for potential applications as wound dressing and tissue engineering scaffold. Composites Science and Technology. 2014;94:132-138. Available from: https://doi.org/ 10.1016/j.compscitech.2014.01.020.

67. Ye S. Morphological, Release and Antibacterial Performances of Amoxicillin-Loaded Cellulose Aerogels. Molecules. 2018;23(8):2082. PMID: 30127283. Available from: https: //doi.org/10.3390/molecules23082082.

68. Navarro JR, et al. Surface-Initiated Controlled Radical Polymerization Approach to In Situ Cross-Link Cellulose Nanofibrils with Inorganic Nanoparticles. Biomacromolecules. 2020;21(5):1952-1961. PMID: 32223221. Available from: https://doi.org/10.1021/acs.biomac.0c00210.

69. Shen $Z$, et al. An ultra-light antibacterial bagasse-AgNP aerogel. Journal of Materials Chemistry B. 2017;5(6):1155-1158. PMID: 32263585. Available from: https://doi.org/10.1039/ C6TB02171A.

70. Salomoni R. Antibacterial effect of silver nanoparticles in Pseudomonas aeruginosa. Nanotechnology, science and applications. 2017;10:115. PMID: 28721025. Available from: https://doi.org/10.2147/NSA.S133415.

71. Tang S, Zheng J. Antibacterial activity of silver nanoparticles: structural effects. Advanced healthcare materials. 2018;7(13):1701503. PMID: 29808627. Available from: https: //doi.org/10.1002/adhm.201701503.

72. Vijaya JJ, et al. Bioreduction potentials of dried root of Zingiber officinale for a simple green synthesis of silver nanoparticles: antibacterial studies. Journal of Photochemistry and Photobiology B: Biology. 2017;177:62-68. PMID: 29069633. Available from: https://doi.org/10.1016/j.jphotobiol.2017.10. 007.

73. Henschen J, et al. Contact-active antibacterial aerogels from cellulose nanofibrils. Colloids and Surfaces B: Biointerfaces. 2016;146:415-422. PMID: 27391038. Available from: https: //doi.org/10.1016/j.colsurfb.2016.06.031.

74. Tarrés Q, et al. Research on the Strengthening Advantages on Using Cellulose Nanofibers as Polyvinyl Alcohol Reinforcement. Polymers. 2020;12(4):974. PMID: 32331220. Available from: https://doi.org/10.3390/polym 12040974.
75. Kumari $P$, et al. Cellulose nanofibers from lignocellulosic biomass of lemongrass using enzymatic hydrolysis: characterization and cytotoxicity assessment. DARU Journal of Pharmaceutical Sciences. 2019;27(2):683-693. PMID: 31654377. Available from: https://doi.org/10.1007/s40199-019-00303-1.

76. Souza SF, et al. Cell interactions and cytotoxic studies of cellulose nanofibers from Curauá natural fibers. Carbohydrate polymers. 2018;201:87-95. PMID: 30241866. Available from: https://doi.org/10.1016/j.carbpol.2018.08.056.

77. Nordli HR, et al. Producing ultrapure wood cellulose nanofibrils and evaluating the cytotoxicity using human skin cells. Carbohydrate polymers. 2016;150:65-73. PMID: 27312614 Available from: https://doi.org/10.1016/j.carbpol.2016.04.094.

78. Shen $X$, et al. Hydrogels based on cellulose and chitin: fabrication, properties, and applications. Green Chemistry. 2016;18(1):53-75. Available from: https://doi.org/10.1039/ C5GC02396C.

79. Liakos IL, et al. Electrospun fiber pads of cellulose acetate and essential oils with antimicrobial activity. Nanomaterials. 2017;7(4):84. PMID: 28417912. Available from: https: //doi.org/10.3390/nano7040084.

80. Moghimi R, Aliahmadi A, Rafati H. Antibacterial hydroxypropyl methyl cellulose edible films containing nanoemulsions of Thymus daenensis essential oil for food packaging. Carbohydrate polymers. 2017;175:241-248. PMID: 28917862. Available from: https://doi.org/10.1016/j.carbpol.2017.07.086.

81. Montes S, Maleki H. Aerogels and their applications. Colloidal Metal Oxide Nanoparticles, Elsevier. 2020;p. 337-399. Available from: https://doi.org/10.1016/B978-0-12-813357-6. 00015-2.

82. Pereira SG, et al. Microbiota of chronic diabetic wounds: ecology, impact, and potential for innovative treatment strategies. Frontiers in microbiology. 2017;8:1791. PMID: 28983285. Available from: https://doi.org/10.3389/fmicb.2017.01791.

83. Wang $C$, et al. Engineering bioactive self-healing antibacterial exosomes hydrogel for promoting chronic diabetic wound healing and complete skin regeneration. Theranostics. 2019;9(1):65. PMID: 30662554. Available from: https: //doi.org/10.7150/thno.29766.

84. Camarero-Espinosa $S$, et al. Elucidating the potential biological impact of cellulose nanocrystals. Fibers. 2016;4(3):21. Available from: https://doi.org/10.3390/fib4030021.

85. Seabra AB, et al. Cellulose nanocrystals as carriers in medicine and their toxicities: A review. Carbohydrate polymers. 2018;181:514-527. PMID: 29254002. Available from: https: //doi.org/10.1016/j.carbpol.2017.12.014.

86. Endes $C$, et al. A critical review of the current knowledge regarding the biological impact of nanocellulose. Journal of nanobiotechnology. 2016;14(1):78. PMID: 27903280. Available from: https://doi.org/10.1186/s12951-016-0230-9. 